\title{
Effects of delayed first feeding on growth of the silver catfish larvae Rhamdia voulezi (Siluriformes: Heptapteridae)
}

\author{
Ariane F. de Limaㄹ, Fernanda F. Andrade², Suelen Fernanda R. Pini², Sergio Makrakis² \\ and Maristela C. Makrakis ${ }^{2}$
}

The effects of the timing of first feeding on the point-of-no-return (PNR) and growth of laboratory reared silver catfish Rhamdia voulezi larvae were studied. The experiment began immediately after the complete absorption of the yolk sac, 3 days after hatching (DAH). The food was provided for the first time on $3^{\text {rd }}, 4^{\text {th }}, 5^{\text {th }}, 6^{\text {th }}, 7^{\text {th }}, 8^{\text {th }}$, and $9^{\text {th }}$ DAH. Zooplankton and newly-hatched Artemia spp. were used to feed the larvae. To evaluate the effect of food deprivation on growth, the standard length and weight of 594 larvae were assessed. Larval growth was significantly affected by the time of first exogenous feeding. The larvae fed from $3^{\text {rd }}$ to $5^{\text {th }} \mathrm{DAH}$ showed a significantly higher development than those fed from $6^{\text {th }} \mathrm{DAH}$. The larvae reached the PNR on $6^{\text {th }}$ DAH. Survival and larval growth strongly depended on the timing of initial feeding. In order to avoid potential mortality by starvation and obtain good growth, the silver catfish larvae $R$. voulezi must establish successful initial feeding within 5 days after hatching.

Keywords: Exogenous feeding, Initial feeding, Larval development, Point-of-no-return, Starvation.

Os efeitos do tempo da alimentação inicial sobre o ponto de não retorno (PNR) e o crescimento de larvas de jundiá Rhamdia voulezi foram estudados em condições laboratoriais. O experimento foi iniciado imediatamente após a completa absorção do saco vitelínico, 3 dias após a eclosão (DAE). O alimento foi fornecido pela primeira vez no 3o, 4o, 5o , 6o , 7o , 8o e 9o DAE. Zooplâncton e Artemia spp. recém-eclodida foram usados para a alimentação das larvas. Para avaliar os efeitos da privação alimentar sobre o crescimento, o comprimento padrão e peso de 594 larvas foram analisados. O crescimento larval foi significativamente afetado pelo tempo da primeira alimentação exógena. As larvas que receberam alimento do 3o ao 5o DAE apresentaram desenvolvimento significativamente maior que aquelas alimentadas mais tardiamente, a partir do 6o DAE. As larvas alcançaram o PNR no 6oD. DAE. A sobrevivência e o crescimento das larvas dependem do momento da alimentação inicial. Para evitar a mortalidade em massa e obter bom crescimento, as larvas de $R$. voulezi precisam estabelecer com sucesso a alimentação inicial até o 5o dia após a eclosão.

Palavras-chave: Alimentação exógena, Alimentação inicial, Desenvolvimento larval, Ponto de não retorno, Privação alimentar.

\section{Introduction}

Many fish larvae depend exclusively on the nutritive reserves of the yolk sac as soon as they hatch (Geurden et al., 2007). Once the endogenous reserves are exhausted, the larvae need to make a successful transition from endogenous to exogenous feeding to assure their survival and growth in that phase (Blaxter, Ehrlich, 1974). Some factors, such as availability and composition of the food (Sánchez-Velasco, 1998), temperature, photoperiod (Paul, 1983; Porter, Bailey, 2007), development of the digestive tract, visual acuity, and the swimming ability of the larvae (Makrakis et al., 2005), are important for a successful feeding transition. When these factors do not comply with the actual larval stage, the larvae may not succeed in their initial feeding, and become vulnerable to starvation (Gisbert et al., 2004; Zhang et al., 2009).

\footnotetext{
${ }^{1}$ Departamento de Ecologia, Instituto de Biologia Roberto Alcântara Gomes, Universidade do Estado do Rio de Janeiro (UERJ), Rua São Francisco Xavier, 524, Maracanã, 20550-013 Rio de Janeiro, RJ, Brazil. ariane.f.1@hotmail.com (corresponding author) ${ }^{2}$ Grupo de Pesquisa em Tecnologia em Ecohidráulica e Conservação de Recursos Pesqueiros e Hídricos (GETECH), Programa de PósGraduação em Recursos Pesqueiros e Engenharia de Pesca, Universidade Estadual do Oeste do Paraná (UNIOESTE), Rua da Faculdade, 645, 85903-000 Toledo, PR, Brazil. (FFA) ferfandrade@gmail.com, (SFRP) suelen.pini@hotmail.com, (SM) sergio.makrakis@unioeste.br, (MCM) maristela.makrakis@unioeste.br
} 
Starvation is one of the major causes of mortality of fish larvae in natural environments, as well as in fish farming (Dou et al., 2002; Yúfera, Darias, 2007). This happens because during the early ontogenetic development, most fish show low swimming and feeding abilities (Houde, 1974; Dou et al., 2002). Hence, if the fishes are deprived from adequate food in this phase, the most notorious results are an increase in vulnerability to predators, mortality, morphological deformities, and reduced growth rates (Houde, 1974; Dou et al., 2002; Zhang et al., 2009; Faria et al., 2011). Food deprivation also affects other biochemical parameters and weight (Hung et al., 1997).

Adults of many fish species can tolerate considerable periods of food deprivation, developing an ability to survive in the absence or scarcity of food and an ability to recover completely if they are fed again (Love, 1970; Salam et al., 2000). The same was not observed in the larval period, since the larvae reach an irreversible state of starvation within a few days. In this state, even if there is food available, they cannot feed anymore and mortality increases sharply. Blaxter, Hempel (1963) denominated this critical stage as point-of-no-return (PNR).

Several methods have been used to describe the effects of food deprivation in adult and larval fish: morphometric and gravimetric measurements (weight) (Peña, Dumas, 2005; Shan et al., 2009; Faria et al., 2011), RNA/DNA content (Faria et al., 2011), histological criteria (Gisbert et al., 2004), enzyme activity (Chen et al., 2007), and swimming ability (Faria et al., 2011). Available research on these issues at present is still scarce and especially targeted at fish larvae of marine species, such as Paralichthys californicus (Ayres, 1859) (Gisbert et al., 2004), Paralabrax maculatofasciatus (Steindachner, 1868) (Penã, Dumas, 2005), Seriola lalandi Valenciennes, 1833 (Chen et al., 2007), Oplegnathus fasciatus (Temminck, Schlegel, 1844) (Shan et al., 2008), and Miichthys miiuy (Basilewsky, 1855) (Shan et al., 2009).

Understanding how starvation may affect the development, growth, and survival of the larvae is crucial to determine the time frame that fishes can tolerate the absence of food before reaching the point-of-no-return (Gisbert et al., 2004; Peña, Dumas, 2005), and may be a useful tool to understand the causes of early mortality of fishes in their natural environment (O'Connell, 1976), as well as in rearing conditions. This study investigates the effects of delayed first feeding on biological parameters in silver catfish larvae, Rhamdia voulezi Haseman, 1911, an endemic species from Iguaçu River Basin in South America, in order to better understand its larval growth during starvation and provide information for feeding management in larval rearing. The biology and ecology of this species are poorly known, and rearing $R$. voulezi is still at an early phase. Specifically, this study will: 1 ) evaluate at what time the yolk sac is exhausted to determine the onset of exogenous feeding, 2) determine when the PNR occurs, and 3) evaluate the effects of delayed first feeding on larval growth of $R$. voulezi.

\section{Material and Methods}

The experiment was conducted in February 2012 at Instituto de Pesquisas em Aquicultura Ambiental (InPAA) of the Universidade Estadual do Oeste do Paraná (UNIOESTE), Toledo, Paraná State, Brazil. The larvae of the silver catfish, $R$. voulezi, were obtained through induced reproduction provided by Centro de Difusão e Desenvolvimento Tecnológico do Rio Iguaçu (CDT), located in Boa Vista da Aparecida, Paraná State, Brazil.

Spawning was induced by injection of carp pituitary extract a dose of $5.5 \mathrm{mg} \mathrm{kg}^{-1}$ for females and $2.5 \mathrm{mg} \mathrm{kg}^{-1}$ for males. The hormonal induction in females was made in two doses: $0.5 \mathrm{mg} \mathrm{kg}^{-1}$ in the first and $5.0 \mathrm{mg} \mathrm{kg}^{-1}$ in second dose, with an interval of 12 hours between them, and a single dose in the males. The ovulation occurred 9 hours after the second hormonal dose. The collection of female and male gametes was performed by abdominal pressure. The average number of ovules per gram of females to species $R$. voulezi is 149 to 158 , and the average volume of semen varies 5.50 to $6.54 \mathrm{~mL}$ (Signor et al., 2013). After fertilization, the eggs were placed in funnel incubators with $20 \mathrm{~L}$, and flow-thru of water provided by an open water system from the Iguaçu River, Paraná State. The mean water temperature during incubation was $29.3^{\circ} \mathrm{C}$.

The hatching of $R$. voulezi larvae occurred 15 hours after fertilization at an average temperature of $29.3^{\circ} \mathrm{C}$. After hatching, the larvae were transferred into a plastic bag with oxygen for transport to InPAA within 90 minutes, and they were maintained in tanks with $30 \mathrm{~L}$ of fresh water with mechanical aeration. At least 30\% of the water volume of these tanks was renewed daily after siphoned to remove the detritus. At this stage, at least twice a day, 10 larvae were collected from these tanks and observed under a microscope their stage of development, the degree of absorption of the yolk sac and the formation of the mouth.

The experiment was completely randomized and began shortly after the absorption of the yolk sac, on the $3^{\text {rd }}$ day after hatching (DAH). Eight treatments were carried out in triplicate with different times of onset of feeding. The food was provided for the first time on the $3^{\text {rd }}, 4^{\text {th }}, 5^{\text {th }}, 6^{\text {th }}, 7^{\text {th }}, 8^{\text {th }}$, and $9^{\text {th }} \mathrm{DAH}$, which corresponded to the treatments T3, T4, T5, T6, T7, T8, and $\mathrm{T} 9$, respectively. In the Fasted Group (FG) no food was provided. The treatments were conducted in plastic recipients with volume of $10 \mathrm{~L}$ each, equipped with a constant aeration system, and density of 20 larvae per liter. The experiments were carried out in the dark, i.e. the tanks were also covered with black plastic. The reason for this is the fact that catfish have higher tactile performance in an environment with no light (Boujard et al., 1988), and Rhamdia quelen (Quoy, Gaimard, 1824) larvae have better grow when exposed to no light (Behr et al., 1999). 
The larvae were fed twice a day: at 9:00 and 16:00 hours, using zooplankton from fish ponds and newlyhatched Artemia spp. In these fish ponds, $\mathrm{CaCO}_{3}(250 \mathrm{~g}$ $\left.\mathrm{m}^{-2}\right)$ and NPK 4-14-8 (200 $\left.\mathrm{g} \mathrm{m}^{-2}\right)$ were previously added to promote the growth of the plankton community. The application of lime in the tank was conducted before the fertilization to increase alkalinity, because it was less than $20 \mathrm{mg} \mathrm{L}^{-1}$. According to Boyd, Scarsbrook (1974), when the sediment of the pond is acid, it may absorb almost all of the added phosphorus fertilizers through, so it damages the primary and secondary production. The zooplankton community that developed in the ponds comes from a river near InPAA, which supplies all fish ponds in this local region. Zooplankton was collected with plankton net (mesh of $68 \mu \mathrm{m}$ ), homogenized, and then distributed equally to all tanks of the experiments (daily mean of 1228 prey L ${ }^{-1}$ ), with the inclusion of Artemia spp. (approximately 368 prey $\mathrm{L}^{-1}$ ). Among zooplankton taxa, copepods, cladorecans and rotifers were found. The copepods were represented by genera: Argyrodiaptomus, Notodiaptomus, Metacyclops and Thermocyclops (also, stages of nauplii and copepodites were found). For cladocerans, the species of the genera Diaphanosoma, Daphnia, Bosmina, Ephemeroporus, Moina and Macrothrix were recorded. For rotifers, the species of the genera Lecane, Trichocerca, Asplanchna, Platyas, and Brachionus were found.

All recipients were siphoned to remove the debris before the last feeding of the day. At this moment, three larvae were sampled from each replica of all treatments.

During the experiments, water temperature $(29.23 \pm 0.14$ $\left.{ }^{\circ} \mathrm{C}\right), \mathrm{pH}(8.23 \pm 0.02)$, dissolved oxygen $(5.10 \pm 0.06 \mathrm{mg}$ $\left.\mathrm{L}^{-1}\right)$, and electrical conductivity $\left(137.31 \pm 1.17 \mu \mathrm{S} \mathrm{cm}^{-1}\right)$ in the tanks were recorded at 17:00 hours every day using a multiparameter probe (YSI Professional Plus).

The larvae collected were euthanized in a benzocaine solution (250 $\left.\mathrm{mgL}^{-1}\right)$ adapted from Coyle et al. (2004) and later they were fixed in formaldehyde $4 \%$, according to the procedure approved by the Ethics Committee of UNIOESTE, for later analysis.

Some behavioral aspects were visually observed, for example, horizontal and erratic swimming, lethargic behavior, isolation of groups and cannibalism. The observation time was approximately 5 minutes daily during feeding.

At the end of the experiment, after 14 days the onset of first feeding, the standard length (SL, $\mathrm{mm}$ ) and weight (g) of 594 larvae were evaluated. Some treatments ended before others due to mortality caused by starvation, and, hence, they had a shorter duration (6-9 days). This explains the difference in the sample size $(\mathrm{N})$ among treatments (Tab. 1). The measurements were made using stereomicroscope (Olympus SZX7) equipped with a digital camera (DP25) with image capture, and the software DP2-BSW. The larvae were weighed using a digital balance (SHIMADZU AW 220, precision of $0.00001 \mathrm{~g}$ ).
Individuals used in this research have been deposited in the Ichthyological Collection of the Núcleo de Pesquisas em Limnologia, Ictiologia e Aquicultura (Nupélia) at the Universidade Estadual de Maringá (UEM), Paraná, Brazil (NUP 18741).

Data analysis. The larval growth submitted to starvation for different periods (treatments) was evaluated using Kruskal-Wallis. The standard length and weight were considered dependent variables and treatments as the independent variable. A multiple comparison test was conducted to determine which treatments were differed. The significance level of 0.05 was considered in these analyzes.

In order to compare the weight/length ratio and the growth coefficient among different treatments, linear regressions were made with log-transformed data (x). The weight/length ratio was observed through the coefficient of determination $\left(\mathrm{R}^{2}\right)$ and the growth coefficient through the value of $b$, which is the regression coefficient extracted from the equation: $y=a+b x$. The software Statistica 7.0 was used to conduct the analysis.

\section{Results}

Hatching and beginning of exogenous feeding. On the $2^{\text {nd }}$ DAH (day after hatching), the mouth was opened. Only on the $3^{\text {rd }} \mathrm{DAH}$ (mean of SL: $4.45 \pm 0.38 \mathrm{~mm}$ -standard deviation; 79 hours after hatching an average temperature of $30^{\circ} \mathrm{C}$ ), the yolk sac was completely absorbed. Cannibalism was observed in all treatments, however it was more common in treatments with delayed first feeding, and specially at T7. It is important to note that, even before the complete exhaustion of the yolk sac, the larvae exhibited typical elements of foraging behavior, such as swimming ability and attempts of capture.

Standard length and weight. The Kruskal-Wallis test showed significant differences between treatments for both standard length $(\mathrm{H}=254.4807 ; P<0.001)$ and weight ( $\mathrm{H}=302.4862 ; P<0.001)$ of the larvae. The multiple comparison test highlighted three distinct groups. The first group (a) was formed by the treatments T3 and T4, the second group (b) by T5, and the third group (c) was formed by the other treatments (T6, T7, T8, T9, and FG) (Tab. 1). Larval growth in standard length and weight was higher in the treatments T3 and T4 (Figs. 1a-b). In the T5, they also exhibited grow (Fig. 1c), but it was slightly lower than T3 and T4. In the treatments T6, T7, T8, T9, and FG, the larvae did not grow because they remained longer without food (Figs. 1d and 2a-d). This indicates that the development of the $R$. voulezi larvae is only possible if the initial feeding is provided on the $3^{\text {rd }}, 4^{\text {th }}$, or $5^{\text {th }} \mathrm{DAH}$. If they are fed after this period, the larval development is interrupted. 
Tab. 1. Results of Kruskal-Wallis analysis $(\mathrm{H})$ for the standard length and weight for Rhamdia voulezi in each treatment in relation to days after hatching (DAH). DF, degrees of freedom; N, number of specimens analyzed; SD, Standard Deviation; FG, Fasted Group.

\begin{tabular}{|c|c|c|c|c|c|c|c|c|}
\hline \multirow{2}{*}{ Treatment } & \multirow{2}{*}{ Temperature ${ }^{\circ} \mathrm{C} \pm \mathrm{SD}$} & \multirow{2}{*}{ DAH } & \multirow{2}{*}{$\mathrm{DF}$} & \multirow{2}{*}{$\mathrm{N}$} & \multicolumn{2}{|c|}{ Standard length $(\mathrm{mm})$} & \multicolumn{2}{|c|}{ Weight $(\mathrm{g})$} \\
\hline & & & & & $\mathrm{H}$ & $P$ & $\mathrm{H}$ & $P$ \\
\hline $\mathrm{T} 4$ & $28,85 \pm 1,26$ & 5 & 13 & 124 & 115.72 & 0.00 & 115.34 & 0.00 \\
\hline T6 & $30,05 \pm 0,66$ & 7 & 3 & 36 & 1.80 & 0.61 & 5.51 & 0.13 \\
\hline $\mathrm{T} 7$ & $29,45 \pm 1,16$ & 8 & 4 & 45 & 8. 50 & 0.07 & 8.50 & 0.07 \\
\hline $\mathrm{T} 8$ & $30,00 \pm 0,54$ & 9 & 4 & 45 & 4. 87 & 0.30 & 5.11 & 0.27 \\
\hline FG & $29,70 \pm 0,57$ & - & 4 & 45 & 5.34 & 0.25 & 7.59 & 0.10 \\
\hline
\end{tabular}
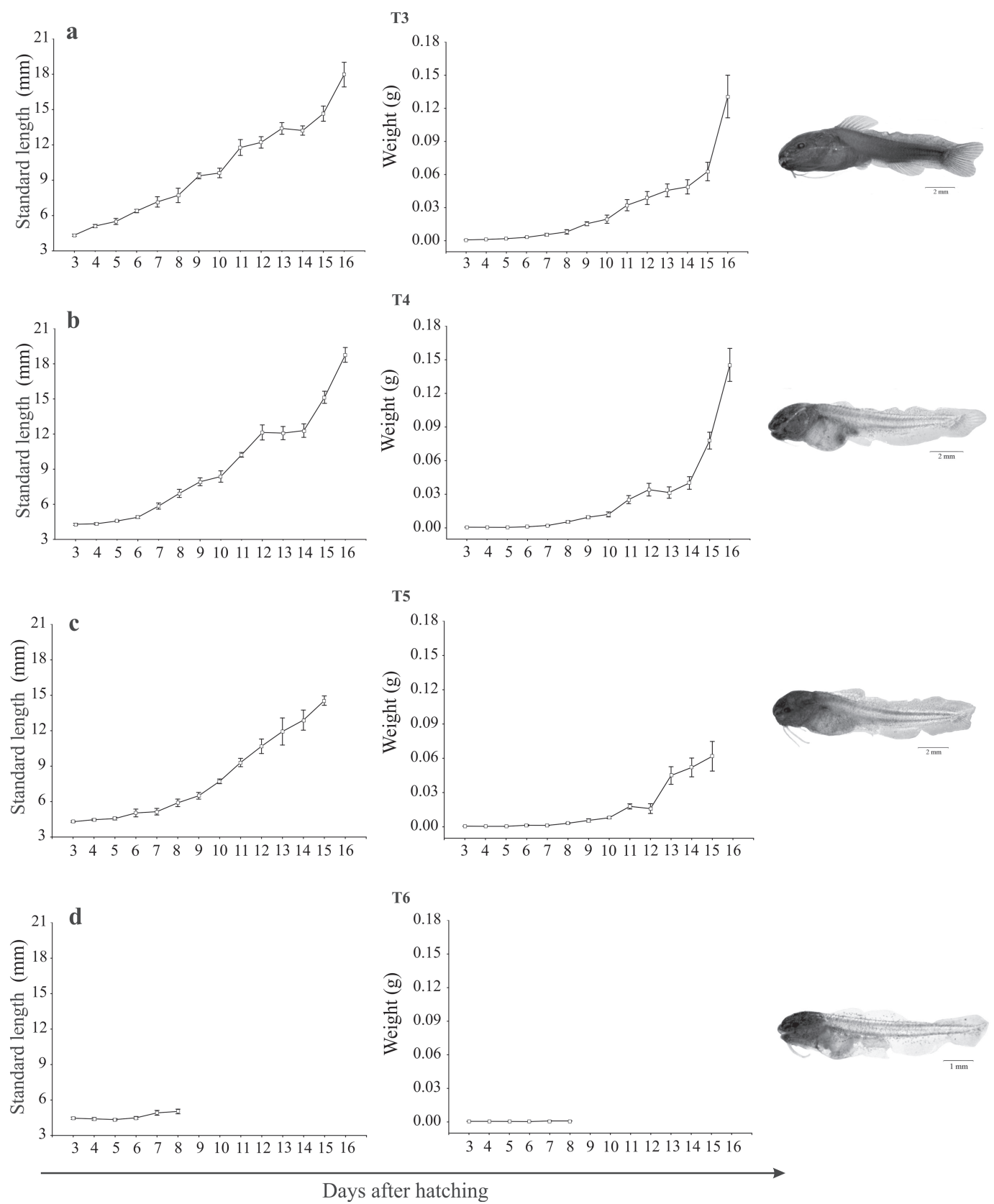

Fig. 1. Standard length (mm) and weight $(\mathrm{g})$ (average \pm standard error) of Rhamdia voulezi in the different days for each treatment: a. larvae fed at $3^{\text {rd }}$ day after hatching (DAH) - T3; b. $4^{\text {th }} \mathrm{DAH}-\mathrm{T} 4 ; \mathbf{c} .5^{\text {th }} \mathrm{DAH}-\mathrm{T}$, and d. $6^{\text {th }} \mathrm{DAH}-\mathrm{T} 6$. 

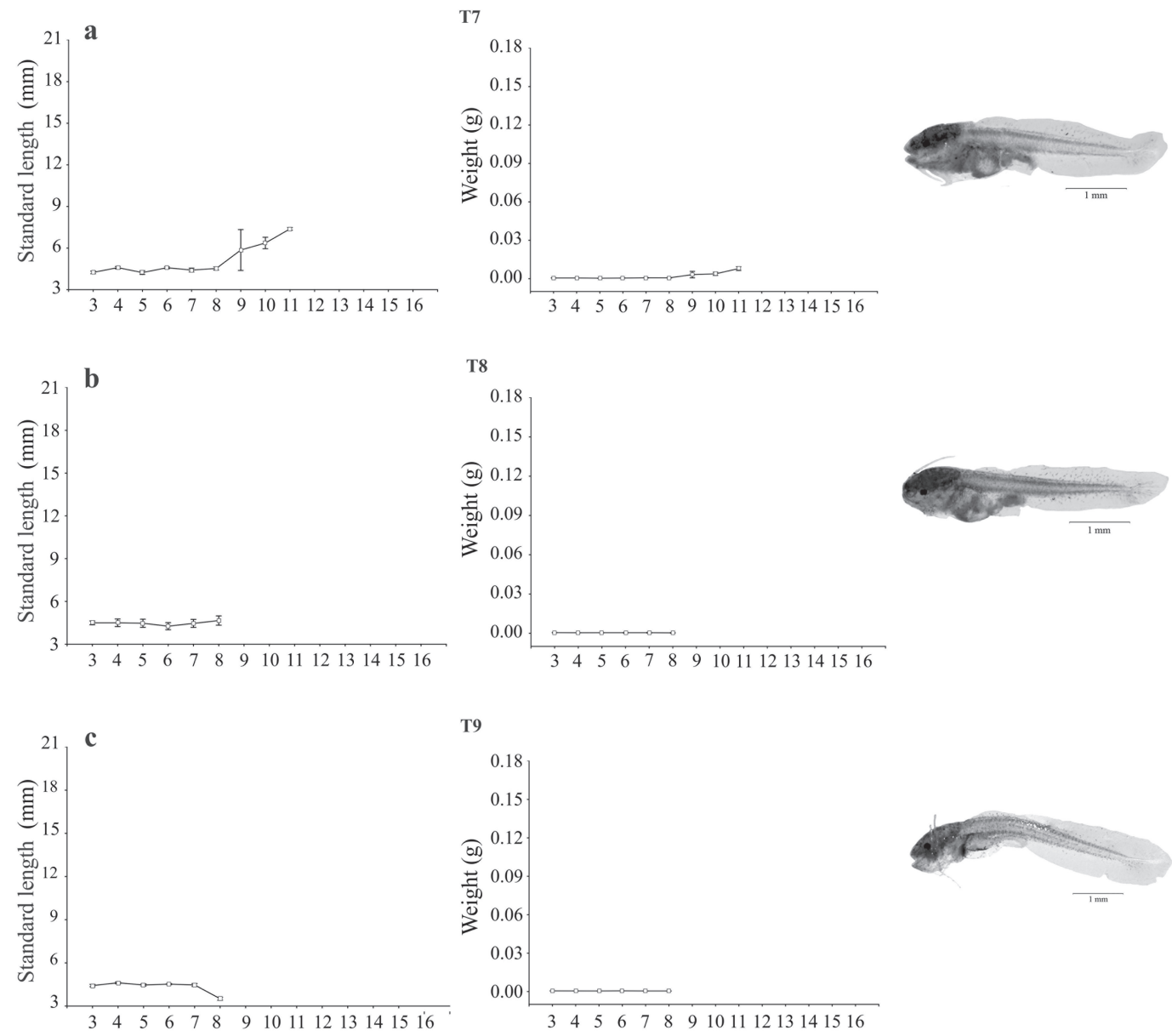

T9
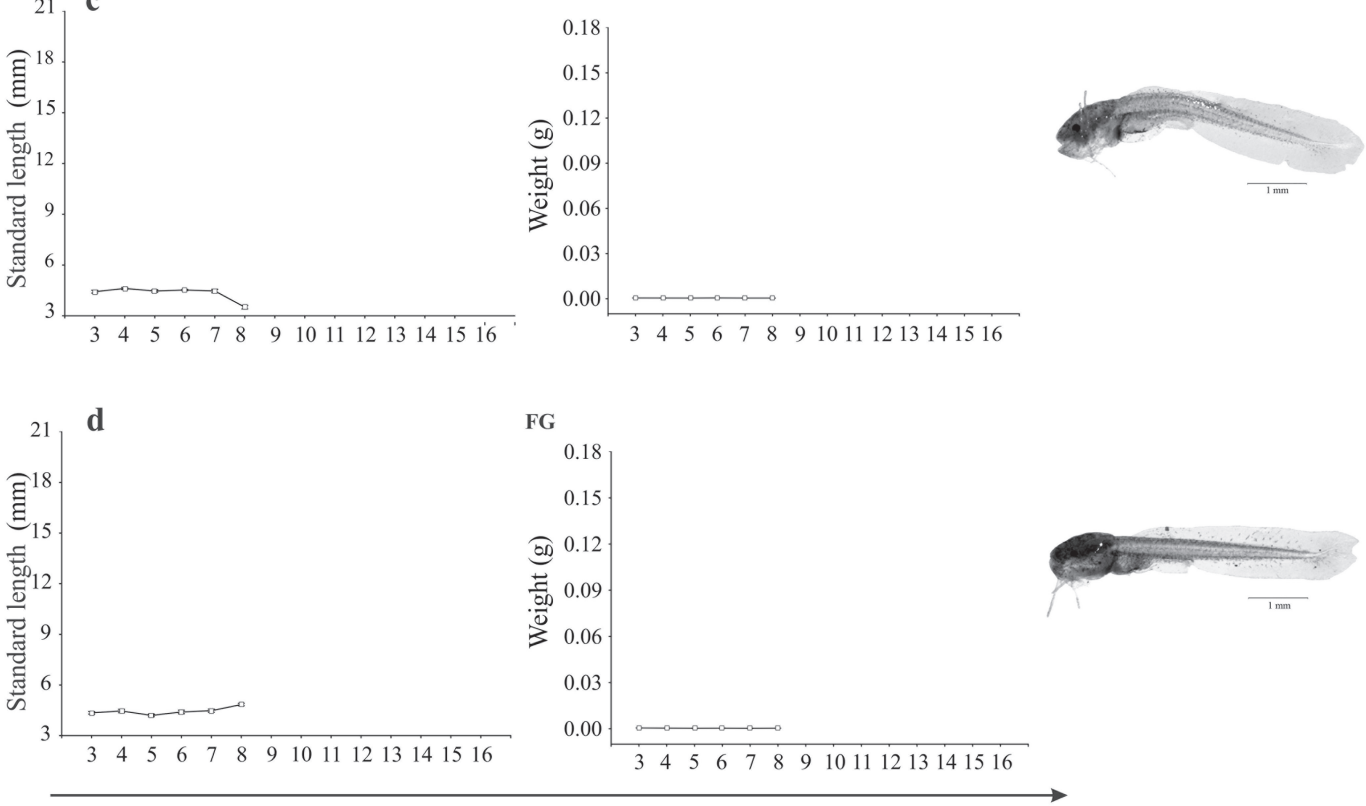

Days after hatching

Fig. 2. Standard length $(\mathrm{mm})$ and weight $(\mathrm{g})$ (average \pm standard error) of Rhamdia voulezi in the different days for each treatment: a. larvae fed at $7^{\text {th }}$ day after hatching $(\mathrm{DAH})-\mathrm{T} 7$; b. $8^{\text {th }} \mathrm{DAH}-\mathrm{T} 8$; c. $9^{\text {th }} \mathrm{DAH}-\mathrm{T}$, and $\mathbf{d}$. Fasted Group - FG.

Point-of-no-return (PNR). The sixth day after hatching $\left(6^{\text {th }}\right.$ DAH; 144 hours after hatching) at an average temperature of $29.3^{\circ} \mathrm{C}$ was characterized as the PNR for the larvae of $R$. voulezi. At the PNR, the larvae did not recover and the death was pronounced (Figs. 1d and 2a-d).

From the $4^{\text {th }}$ DAH on, cannibalism was observed in larvae subjected to starvation, showing signs of injury and shredded fins. In addition, changes in swimming behavior were noticed: some larvae exhibited horizontal swimming and signs of lethargy. Contrary to the larvae with normal swimming, that exhibited continuous body movements using pectorals and caudal fins, and burst swimming, when they were disturbed by manipulation in the experiment (feeding and cleaning of tanks and reading of the abiotic factors).

Weight and standard length ratio. The linear regression of the weight as a function of standard length in different treatments indicates that only in the treatments T3, T4, and $\mathrm{T} 5\left(3^{\text {rd }}, 4^{\text {th }}\right.$, and $\left.5^{\text {th }} \mathrm{DAH}\right)$ the weight was strongly associated with a variation in the standard length (Figs. 3a-c).

The coefficient of determination was not significant for the treatments T6, T7, T8, T9, and FG either (Figs. 3d-h). 

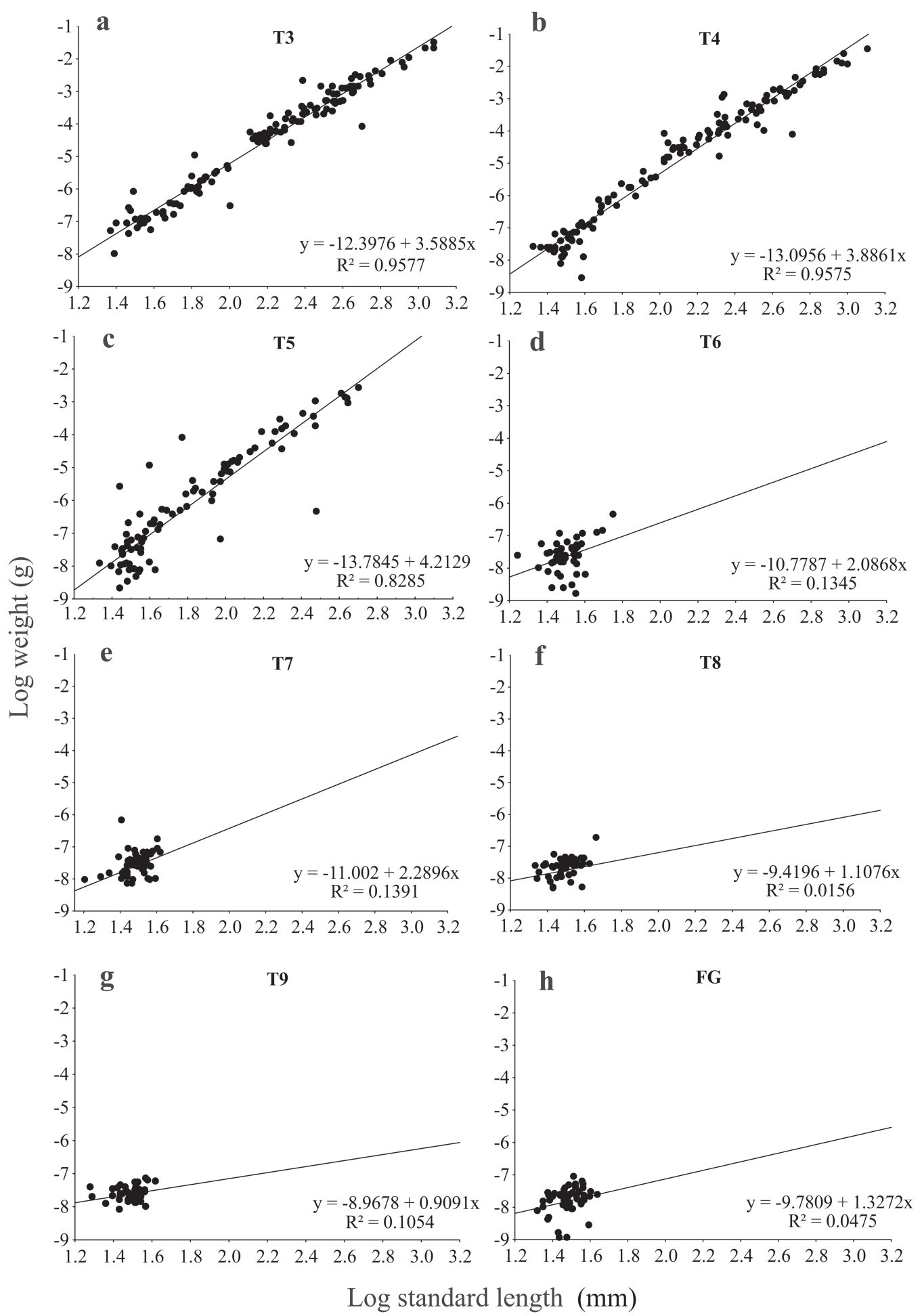

Fig. 3. Log weight/log standard length (SL) ratio of Rhamdia voulezi at different days of first feeding: a. larvae fed at $3^{\text {rd }}$ day after hatching (DAH ) - T3; b. $4^{\text {th }}$ DAH - T4; c. $5^{\text {th }}$ DAH - T5; d. $6^{\text {th }}$ DAH - T6; e. $7^{\text {th }}$ DAH - T7; f. $^{\text {th }}$ DAH - T8; g. $9^{\text {th }}$ DAH - T9, and h. Fasted Group - FG.

The growth pattern observed based on the regression coefficient (b) shows that weight increased more than standard length $(\mathrm{b}>3)$ for $\mathrm{T} 3, \mathrm{~T} 4$, and $\mathrm{T} 5\left(3^{\text {rd }}, 4^{\text {th }}\right.$, and $5^{\text {th }}$ $\mathrm{DAH})$. There was a marked decrease from $\mathrm{T} 6$, and this suggests the PNR on the $6^{\text {th }}$ DAH (Fig. 4). However, the
T7 showed a positive allometry of the weight as a function of growth considering a few cannibalistic larvae (7 of the total of 59 larvae) observed in this treatment (Fig. 4). In the others treatments, the presence of cannibalistic larvae was negligible. 


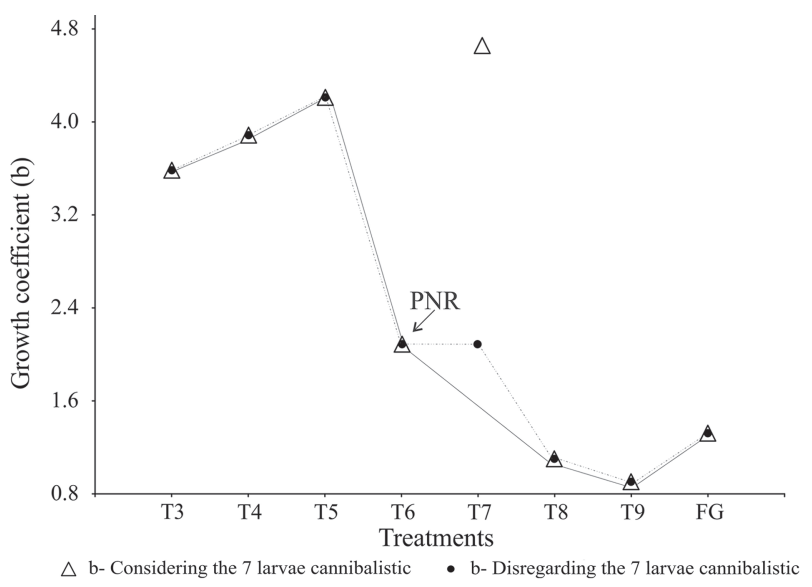

Fig. 4. Growth coefficients of Rhamdia voulezi larvae according to the day of first feeding. Larvae fed at $3^{\text {rd }}$ day after hatching $(\mathrm{DAH})-\mathrm{T} 3 ; 4^{\text {th }} \mathrm{DAH}-\mathrm{T} 4 ; 5^{\text {th }} \mathrm{DAH}-\mathrm{T} 5 ; 6^{\text {th }}$ DAH - T6; $7^{\text {th }}$ DAH - T7; $8^{\text {th }}$ DAH - T8; $9^{\text {th }} \mathrm{DAH}-\mathrm{T}$, and Fasted Group - FG. PNR = point of no return.

\section{Discussion}

The time of the initial feeding varies between fish species and is generally influenced by factors such as egg size and temperature (Shan et al., 2008). In this study, larvae of $R$. voulezi completed exhaustion of the yolk sac 3 days after hatching (mean water temperature of $29.3^{\circ} \mathrm{C}$ ) and delayed first feeding influenced the larval growth. Some fish species may pass through a period of mixed feeding before the complete exhaustion of the vitelline reserves (Zhang et al., 2009), whereas others only begin their initial feeding shortly after the total absorption of the yolk sac (Houde, 1974), or days after its absorption (Gisbert, Williot, 1997; Gisbert et al., 2004). Nakaghi et al. (2011) showed that for tilapia larvae (Oreochromis niloticus) an initial feeding before or shortly after the total depletion of the yolk sac did not influence their survival.

It is well known that the larval period is characterized by high mortality rates, mainly in the transition from the endogenous to exogenous feeding (Fuiman, 2002). The survival and growth in this phase depends on, among other factors, the degree of development of some organs and on structures necessary for feeding, such as mouth, digestive tract (Makrakis et al., 2005, 2008), swimming ability, which is related to the success in food search, visual acuity (Yúfera, Darias, 2007; Makrakis et al., 2008), and food availability (Sánchez-Velasco, 1998). Larvae that cannot overcome these limitations in time, become vulnerable to starvation and, consequently, to predation (Gisbert et al., 2004; Dou et al., 2005).

Early starvation may result in serious morphological deformities, growth delay, and high mortality (Gisbert et al., 2004; Shan et al., 2009). The PNR of $R$. voulezi larvae was reached on the $6^{\text {th }} \mathrm{DAH}$ at a temperature of $29.3^{\circ} \mathrm{C}$. The treatments that received food after the PNR kept showing high mortality and did not show a development pattern similar to the treatments that received food early (until the $\left.5^{\text {th }} \mathrm{DAH}\right)$.

The capacity to resist food deprivation before the PNR depends on the larval size, temperature, and the fish species (Blaxter, Ehrlich, 1974; Houde, 1974). For example, for the freshwater species, Odontesthes bonariensis (Valenciennes, 1835), the PNR occurred on the eighth day after hatching at $26^{\circ} \mathrm{C}$ (Strussmann, Takashima, 1989). However, for the marine species, Paralichthys californicus, the PNR occurred on the $7^{\text {th }} \mathrm{DAH}$ at $18^{\circ} \mathrm{C}$ (Gisbert et al., 2004) and for Paralabrax maculatofasciatus, it occurred on the fourth or fifth day after hatching (in approximately $24^{\circ} \mathrm{C}$ ) (Peña, Dumas, 2005). For Neotropical fishes there is no information regarding the PNR. According to Lima et al. (2017), larvae of $R$. voulezi are highly specific in the choice of their prey, and therefore the survival and growth in hatchery systems verified by Borges Neto et al. (2013) for R. quelen depend on the supply of live prey, because their larvae have difficulties assimilating artificial diets.

Morphological and biochemical methods have been used to assess the condition of fish larvae subjected to different periods of food deprivation. In the present study, the delay in initial feeding was assessed through growth (standard length) and weight, which were strongly affected in larvae with delayed initial feeding (after the $5^{\text {th }} \mathrm{DAH}$ ). In larvae of other freshwater species, such as Lates calcarifer (Bloch, 1790) (Kailasam et al., 2007) and Siniperca scherzeri Steindachner, 1892 (Zhang et al., 2009), the growth was also influenced by the delay in initial feeding. It is worth mentioning that changes in behavior, such as lethargy, erratic swimming (horizontal swimming), and cannibalism, observed in the present study, may be the first signs of starvation. Swimming is one of the most important behaviours in larval fish, determining largely the success of predator avoidance, prey capture and dispersal potential (Armsworth, 2001). Changes in swimming behavior have also been reported in other studies, such as Laurence (1972), Yin, Blaxter (1986), and Skajaa, Browman (2007).

The ability to tolerate certain periods of food deprivation is crucial to larval survival and growth (Chen et al., 2007). However, food deprivation should be avoided before the complete development of the larvae, because it may damage gut cells, which are important to digestion and food absorption. Notwithstanding this hypothesis, Dou et al. (2002) alerted that the initial feeding provided close to the PNR reduces the ability of larvae to feed, due to morphological and physiological deformities caused by starvation. In conclusion, our results indicate that the silver catfish, $R$. voulezi, are susceptible to food deprivation: the initial development is fast with exhaustion of the yolk sac in a few days - $3^{\text {rd }}$ DAH. The larval growth was significantly affected by the delay in feeding, exhibiting high mortality and cannibalism. In addition, initial feeding should start before the complete absorption of the yolk sac, and it is tolerable until $5^{\text {th }} \mathrm{DAH}$. The larvae of $R$. voulezi reach the PNR, on $6^{\text {th }} \mathrm{DAH}$ (Fig. 5), and from this period they are no 
longer able to develop, even if the food is provided for the first time. Information about the effects of food deprivation on the development of $R$. voulezi larvae, as well as the maximum time that the larvae are able to resist before the PNR, are important to fish farming. Such information helps to create a protocol of the ideal timing for the beginning of the initial feeding, avoiding high mortality in the larval period.

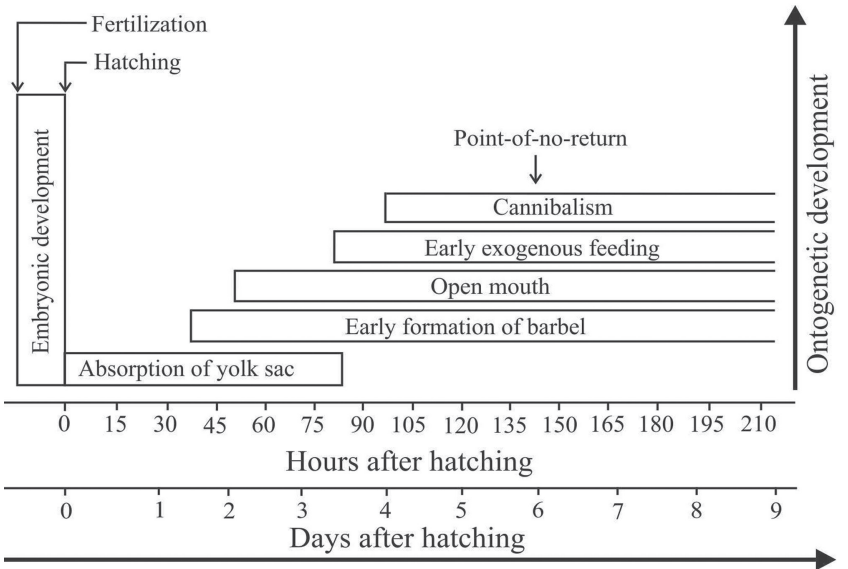

Fig. 5. Major events observed during the ontogeny of Rhamdia voulezi. Mean water temperature of $29.2^{\circ} \mathrm{C}$.

\section{Acknowledgments}

We are grateful to the "Grupo de Pesquisa em Tecnologia em Ecohidráulica e Conservação dos Recursos Pesqueiros e Hídricos (GETECH) - UNIOESTE" for logistic support during fieldwork. The present study is part of the MS.c. Thesis of the first author and was supported by "Coordenação de Aperfeiçoamento de Pessoal de Nível Superior - CAPES". Special thanks to the "Grupo de Estudos em Aquicultura (GEMAq) UNIOESTE" for providing the samples of fish larvae and the colleagues Claudia Costa Bonecker, Diogo Castanho Amaral and Nadson R Simões from "Núcleo de Pesquisas em Limnologia, Ictiologia e Aquicultura (NUPÉLIA) - Universidade Estadual de Maringá (PR)" for helping with the identification of zooplankton species. We also thank Prof. Dr. David Augusto Reynalte-Tataje and the anonymous reviewers of this journal, for providing insightful comments on this manuscript.

\section{References}

Armsworth PR. Directed motion in the sea: efficient swimming by reef fish larvae. J Theor Biol. 2001; 210(1):81-91.

Behr ER, Radünz Neto J, Tronco AP, Fontana AP. Influência de diferentes níveis de luminosidade sobre o desempenho de larvas de Jundiá (Rhamdia quelen) (Quoy e Gaimard, 1824) (Pisces: Pimelodidae). Acta Sci. 1999; 21(2):325-30.

Blaxter JHS, Hempel G. The influence of egg size on herring larvae (Clupea harengus L.). ICES J Mar Sci. 1963; 28(2):211-40.
Blaxter JHS, Ehrlich KF. Changes in behavior during starvation of herring and plaice larvae. In: Blaxter JHS, editor. The early life history of fish. Berlin Heidelberg, New York: Springer Verlag; 1974. p.575-588.

Borges Neto PG, Dutra FM, Ballester ELC, Portz L. Crescimento e sobrevivência de larvas do jundiá, Rhamdia quelen, alimentadas com alimento vivo enriquecido e dieta artificial. Rev Bras Cienc Vet. 2013; 20(4):216-21.

Boujard T, Le Bail P-Y, Planquette P. Données biologiques sur quelques espèces continentales de Guyane Française d'intérêt piscicole. Aquat Living Resour. 1988; 1(2):107-13.

Boyd CE, Scarsbrook E. Effects of agricultural limestone on phytoplankton communities of fish ponds. Arch Hydrobiol. 1974; 74(3):333-49.

Chen BN, Qin JG, Carragher JF, Clarke SM, Kumar MS, Hutchinson WG. Deleterious effects of food restrictions in yellowtail kingfish Seriola lalandi during early development. Aquaculture. 2007; 271(1-4):326-35.

Coyle SD, Durborow RM, Tidwell JH. Anesthetics in aquaculture. Stoneville: Southern Regional Aquaculture Center; 2004. (SRAC Publication; no. 3900).

Dou SZ, Masuda R, Tanaka M, Tsukamoto K. Feeding resumption, morphological changes and mortality during starvation in Japanese flounder larvae. J Fish Biol. 2002; 60(6):1363-80.

Dou SZ, Masuda R, Tanaka M, Tsukamoto K. Effects of temperature and delayed first feeding on survival and growth of Japanese flounder larvae. J Fish Biol. 2005; 66(2):362-77.

Faria AM, Muha T, Morote E, Chícharo MA. Influence of starvation on the critical swimming behaviour of the Senegalese sole (Solea senegalensis) and its relationship with RNA/DNA ratios during ontogeny. Sci Mar. 2011; 75(1):87-94.

Fuiman LA. Special considerations of fish eggs and larvae. In: Fuiman LA, Werner RG, editors. Fishery science: the unique contributions of early life stages. Oxford: Blackwell Science; 2002. p.1-32.

Geurden I, Aramendi M, Zambonino-Infante J, Panserat S. Early feeding of carnivorous rainbow trout (Oncorhynchus mykiss) with a hyperglucidic diet during a short period: effect on dietary glucose utilization in juveniles. Am J Physiol Regul Integr Comp Physiol. 2007; 292(6):2275-83.

Gisbert E, Williot P. Larval behavior and effect of the timing of initial feeding on growth and survival of Siberian sturgeon (Acipenser baeri) larvae under small scale hatchery production. Aquaculture. 1997; 156(1-2):63-76.

Gisbert E, Conklin DB, Piedrahita RH. Effects of delayed first feeding on the nutritional condition and mortality of California halibut larvae. J Fish Biol. 2004; 64(1):116-32.

Houde ED. Effects of temperature and delayed feeding on growth and survival of larvae of three species of subtropical marine fishes. Mar Biol. 1974; 26(3):271-85.

Hung SSO, Liu W, Li H, Storebakken T, Cui T. Effect of starvation on some morphological and biochemical parameters in while sturgeon, Acipenser transmontanus. Aquaculture. 1997; 151(1):357-63. 
Kailasam M, Thirunavukkarasu AR, Selvaraj S, Stalin P. Effect of delayed initial feeding on growth and survival of Asian sea bass Lates calcarifer (Bloch) larvae. Aquaculture. 2007; 271(1-4):298-306.

Laurence GC. Comparative swimming abilities of fed and starved larval largemouth bass (Micropterus salmoides). J Fish Biol. 1972; 4(1):73-78.

Lima AF, Makrakis MC, Andrade FF, Kashiwaqui EAL, Gimenes MF, Makrakis S. Feeding selectivity in early life stages of Rhamdia voulezi under experimental conditions. Aquacult Res. 2017; 48(4):1618-28.

Love RM. The chemical biology of fishes. London: Academic Press; 1970.

Makrakis MC, Nakatani K, Bialetzki A, Gomes LC, Sanches PV, Baumgartner G. Relationship between gape size and feeding selectivity of fish larvae from a Neotropical Reservoir. J Fish Biol. 2008; 72(7):1690-707.

Makrakis MC, Nakatani K, Bialetzki A, Sanches PV, Baumgartner $\mathrm{G}$, Gomes LC. Ontogenetic shifts in digestive tract morphology and diet of fish larvae of the Itaipu Reservoir, Brazil. Environ Biol Fishes. 2005; 72(1):99-107.

Nakaghi LSO, Batista WK, Paes MCP, Makino LC, Koberstein TCRD. Influence of the first feeding on absorption of yolk and survival rate of Oreochromis niloticus larvae. Rev Acad, Cienc Agrar Ambient. 2011; 9:257-62.

O'Connell CP. Histological criteria for diagnosing the starving condition in early post yolk sac larvae of the northern anchovy, Engraulis mordax Girard. J Exp Mar Biol Ecol. 1976; 25(3):285-312.

Paul AJ. Light, temperature, nauplii concentrations, and prey capture by first feeding pollock larvae Theragra chalcogramma. Mar Ecol Prog Ser. 1983; 13(2-3):175-79.

Peña RA, Dumas S. Effect of delayed first feeding on development and feeding ability of Paralabrax maculatofasciatus larvae. J Fish Biol. 2005; 67(3):640-51.

Porter SM, Bailey KM. Optimization of feeding and growth conditions for walleye pollock Theragra chalcogramma (Pallas) larvae reared in the laboratory. Seattle: Alaska Fisheries Science Center, NOAA, National Marine Fisheries Service; 2007. (AFSC processed report; 2007-06).
Salam A, Ali M, Masud S. Effect of various food deprivation regimes on body composition dynamics of thaila, Catla catla. J Res (Sci). 2000; 11(1):26-32.

Sánchez-Velasco L. Diet composition and feeding habits of fish larvae of two co-occurring species (Pisces: Callionymidae and Bothidae) in the North-western Mediterranean. ICES J Mar Sci. 1998; 55(2):299-308.

Shan X, Quan H, Dou S. Effects of delayed first feeding on growth and survival of rock bream Oplegnathus fasciatus larvae. Aquaculture. 2008; 277(1-2):14-23.

Shan X, Cao L, Huang W, Dou S. Feeding, morphological changes and allometric growth during starvation in miiuy croaker larvae. Environ Biol Fishes. 2009; 86(1):121-30.

Signor A, Feiden A, Boscolo WR, Signor AA, Gonçalves GS, Sary C, Klein S. Eventos reprodutivos do jundiá Rhamdia voulezi cultivado em tanques-rede. Rev Brasil Reprod Anim. 2013; 37(3):272-77.

Skajaa K, Browman HI. The escape response of food-deprived cod larvae (Gadus morhua L.). J Exp Mar Biol Ecol. 2007; 353(2):135-44.

Strussmann CA, Takashima F. PNR, histology and morphometry of starved pejerrey Odontesthes bonariensis larvae. Nippon Suisan Gakkaishi. 1989; 55(2):237-46.

Yin MC, Blaxter JHS. Morphological changes during growth and starvation of larval cod (Gadus morhua L.) and flounder (Platichthys flesus L.). J Exp Mar Biol Ecol. 1986; 104(1):21528.

Yúfera M, Darias MJ. The onset of exogenous feeding in marine fish larvae. Aquaculture. 2007; 268(1-4):53-63.

Zhang L, Wang YJ, Hu MH, Fan QX, Cheung SG, Shin PKS, Li $\mathrm{H}$; Cao L. Effects of the timing of initial feeding on growth and survival of spotted mandarin fish Siniperca scherzeri larvae. J Fish Biol. 2009; 75(6):1158-72.
Submitted June 25, 2015

Accepted March 13, 2017 by Andrea Bialetzki 
